\title{
Hubungan Dukungan Teman Sebaya, Kecerdasan Emosional dengan Perilaku Hedonis Siswa Kelas XI di SMA Negeri 1 Tarakan
}

\author{
Fitri Haerunisa Rudiani*, M. Ramli, Yuliati Hotifah \\ Universitas Negeri Malang, Jl. Semarang No. 5 Malang, Jawa Timur, Indonesia \\ *Penulis korespondensi, Surel: f_rudiani@yahoo.com
}

Paper received: 3-5-2021; revised: 24-5-2021; accepted: 28-5-2021

\begin{abstract}
This study aims to see the relationship between peer support, emotional intelligence and the hedonic behavior of class XI students of SMA Negeri 1 Tarakan. This research is this research. The population in this study were students at SMA Negeri 1 Tarakan. The sample was taken using proportional random sampling technique with a sample size of 104 students. Data obtained by peer support scale, intelligence intelligence and hedonic behavior scale. Research data analyzed using multiple regression. The results showed that (1) there was a relationship between peer support and hedonic behavior with sig. less than 0.05 with an effective contribution of 0.4 percent, (2) there is a relationship between emotional intelligence and hedonic behavior with sig less than 0.05 with an effective contribution of 8.5 percent, and (3) peer support and intelligence together are related to behavior hedonic with sig. less than 0.05 and the effective contribution was 8.9 percent.
\end{abstract}

Keywords: peer support; emotional intelligence; hedonic behavior

\begin{abstract}
Abstrak
Penelitian ini bertujuan untuk mengetahui hubungan dukungan teman sebaya, kecerdasan emosional dengan perilaku hedonis siswa kelas XI SMA Negeri 1 Tarakan. Penelitian ini adalah penelitian korelasi. Populasi dalam penelitian ini adalah siswa di SMA Negeri 1 Tarakan. Sampel diambil dengan menggunakan teknik proportional random sampling dengan jumlah sampel 104 siswa. Data diperoleh dengan skala dukungan teman sebaya, skala kecerdasan emosional dan skala perilaku hedonis. Analisis data menggunakan regresi berganda. Hasil penelitian menunjukan bahwa (1) terdapat hubungan antara dukungan teman sebaya dan perilaku hedonis dengan sig. kurang dari 0,05 dengan sumbangan efektif sebesar 0,4 persen, (2) terdapat hubungan antara kecerdasan emosional dan perilaku hedonis dengan sig kurang dari 0,05 dengan sumbangan efektif sebesar 8,5 persen, dan (3) dukungan teman sebaya dan kecerdasan emosional bersama-sama berhubungan dengan perilaku hedonis dengan sig. kurang dari 0,05 dan sumbangan efektifnya sebesar 8,9 persen.
\end{abstract}

Kata kunci: dukungan teman sebaya; kecerdasan emosional; perilaku hedonis

\section{Pendahuluan}

Menurut Salam (2000) hedon berarti kesenangan (pleasure). Prinsip hedonis menduga jika sesuatu dipercaya baik apabila serasi dengan kebahagiaan yg didapatkannya, kebalikannya objek yg mendatangkan penderitaan ataupun tidak membahagiakan serta kesusahan, dievaluasi tidak baik. Orang yang mempunyai perilaku hedonis beranggapan bahwa kesenangan menjadi tujuan utama hidupnya. Sudiantara (2003) berkata kalau hedonis merupakan sesuatu aliran yang berpikiran kalau cuma satu perihal yang sangat baik untuk manusia, ialah kesenangan ataupun kenikmatan. Pemikiran ini sangat mempengaruhi pada kehidupan manusia serta pada kesimpulannya manusia cuma hendak mengejar kesenangan serta kenikmatan itu. Susanto (2001) melaporkan kalau kesamaan gaya hidup hedonis lebih bahagia ketika mengisi waktunya di mall, cafe serta restoran-restoran kuliner siap saji. 
Individu yang mempunyai kecenderungan gaya hidup hedonis hendak berupaya buat cocok memakai status sosial hedon. Bagi Susanto (2001) anak muda yang mempunyai kecenderungan style hidup hedonis hendak berupaya buat cocok dengan status sosial hedon.

Pada usia 15 hingga 20 tahun ini merupakan masa kesempurnaan anak muda (adolescence proper) serta ialah puncak dari pertumbuhan emosi. Dalam sesi ini terjalin pergantian dari mementingkan diri serta mencermati kepentingan orang lain serta kecenderungan mencermati harga diri (Muss, 1968). Anak muda yang mengerti hendak tugas perkembangannya bisa menciptakan kebahagiaan serta bisa melakukan tugas- tugas perkembangannya. Namun anak muda yang tidak mengenali tugas pertumbuhan dalam kehidupannya, hingga anak muda tersebut bisa merasa kandas, merasa tidak senang serta kesusahan menempuh tugas perkembangannya.

Bersumber pada analisis informasi kecerdasan emosional mahasiswa pria serta wanita ditemui kalau kecerdasan emosional mahasiswa pria lebih besar secara signifikan dari kecerdasan emosional mahasiswa wanita. Hasil riset ini berlawanan pada kepercayaan tiap hari kalau kecerdasan emosional wanita lebih besar daripada pria sebab perempuan diharapkan oleh budaya buat lebih atensi, penuh uraian terhadap orang lain, lebih ekspresif daripada pria, serta lebih emosional (Macionis, 1991). Demikian pula hasil riset ini berbeda dari hasil riset Ramli (2007) yang menciptakan kalau tidak terdapat perbandingan kecerdasan emosional bersumber pada tipe kelamin (Ramli \& Widada, 2018).

Suatu riset yang dicoba oleh Mintel menciptakan kalau dalam perihal pakaian, kalangan wanita (79\%) biasanya lebih mempunyai kemauan serta kebutuhan buat penampilan yang modis dari pada kalangan pria (40\%). Kalangan wanita (30\%), banyak perihal lebih bahagia serta fokus di penampilan individu dari pada pria (3\%). dibanding pria, wanita dalam banyak permasalahan lebih kerap dijadikan objek penawaran serta sasaran pasar ataupun mall. Di mata ndustri, wanita lebih mengutamakan penampilan, kalangan wanita pula suka berdandan ataupun membuat cantik diri, seperti itu sebabnya industri lebih mengutamakan kebutuhan wanita (Suyanto, 2013).

Bagi susanto (Martha dkk, 2008) orang yg mempunyai gaya hidup hedonis individu tadi hendak usaha supaya biar cocok memakai status sosial hedonis, lewat style hidup yang tercermin dengan simbol-simbol tertentu, semacam brand yg terkenal serta mahal yang dipakai pada kehidupan sehari-hari. Bagi Kartono (1997), hedonis berasal dari kata hedonisme yg berarti style hidup ataupun pemikiran hidup yang menyangka kalau kesenangan serta kenikmatan modul merupakan tujuan utama hidup. Jika terdapat perihal baik yang cocok dengan tujuan orang hendak dapat tingkatkan kesenangan orang itu sendiri, kebalikannya bila tujuan yang terbuat tidak tercapai hingga hendak kurangi kesenangan orang tersebut. Kesenangan pula bisa identik dengan duit serta berbelanja cocok kebutuhan ataupun kemauan.

Terkait perilaku hedonis orang ditemukan bahwa mall merupakan tempat nongkrong paling digemari buat mengisi ketika senggang remaja (30,8\%), sesertagkan membeli snack adalah pengeluaran yang paling banyak bagi remaja $(49,4 \%)$, sehabis itu membeli alat sekolah seperti, buku serta alat tulis lainnya $(19,5 \%)$, liburan atau jalan-jalan $(9,8 \%)$, pengeluaran buat membeli baju $(9,4 \%)$, menabung $(8,8 \%)$, membeli DVD $(2,3 \%)$, membeli aksesori mobil $(0,6 \%)$ serta adapun yang tidak memberikan jawaban sebanyak $(0,4 \%)$. Dari output informasi lapangan tadi telah pertanda bahwa pengaruh menurut modernisasi menciptakan perilaku remaja menjadi hedonis merupakan kenyataan yang didapat pada lapangan lewat informasi lapangan yang dicoba oleh Kasali (1998). 
Pada zaman saat ini dengan banyak pusat perbelanjaan semacam mall dengan ditambahnya banyak olshop yang berjualan online yang tidak mewajibkan kita bisa langsung dipusat perbelanjaan itu, dengan kita membuka hp serta membuka aplikasi olshop semacam shopee, tokopedia, lazada dll, kita langsung dapat membeli benda yang kita mau. Dengan teknologi yang telah sangat tumbuh membuat banyak anak anak muda yang berfoya- foya buat membeli suatu benda yang diinginkannya serta ikatan pertemanan dengan sahabat yang suka berfoya- foya pula bisa membuat anak muda tersebut mengikut style hidup hedonis tersebut yang membuat anak muda tersebut tidak dapat mengendalikan dirinya buat berfoya- foya.

\section{Metode}

Penelitian ini menggunakan penelitian kuantitatif dengan rancangan korelasional dengan tujuan untuk mengetahui hubungan variabel dukungan teman sebaya, kecerdasan emosional dan perilaku hedonis. Populasi dalam penelitian ini adalah siswa kelas XI SMA Negeri 1 Tarakan dengan jumlah siswa 346 siswa. Penelitian ini diambil menggunakan teknik proportional random sampling dimana setiap unsur populasi untuk dipilih menjadi anggota. Sampel dari populasi dilakukan secara acak tanpa memperhatikan strata yang ada dalam populasi itu. Besaran populasi kelas XI di SMA Negeri 1 Tarakan adalah 346 orang siswa. Peneliti mengambil 30\% dari keseluruhan jumlah populasi untuk dijadikan sampel penelitian. Maka, jumlah sampel penelitian ini adalah 104 orang siswa.

Pengumpulan data dalam penelitian ini menggunakan skala dukungan teman sebaya, skala kecerdasan emosional dan skala perilaku hedonis. Instrumen yang diberikan berupa item pernyataan yang diberikan kepada siswa melalui google form dengan menggunakan 4 kategori jawaban yaitu: (SS) sangat setuju (S) setuju (KS) kurang setuju (TS) tidak setuju. Teknik analisis data yang digunakan adalah analisis regresi berganda untuk mengetahui hubungan variabel satu dengan variabel yang lain dengan menggunakan SPSS 23 for windows dalam proses analisis data. Untuk melihat hasil analisis regresi ganda terlebih dahulu melakukan uji F, jika nilai sig. < 0,05 maka dapat dikatakan signifikansi, sedangkan jika nilai sig. > 0,05 maka dapat dikatakan tidak signifikansi. Selanjutnya dihitung sumbangan efektif pada masingmasing variabel independen dalam penelitian.

\section{Hasil dan Pembahasan}

\subsection{Hasil}

\subsubsection{Dukungan teman sebaya siswa SMA Negeri 1 Tarakan}

Hasil analisis instrumen dukungan teman sebaya menggambarkan dukungan teman sebaya siswa di SMA Negeri 1 Tarakan secara umum. Dukungan teman sebaya dilihat dari 3 kategori yaitu: tinggi, sedang, dan rendah. Siswa dengan dukungan teman sebaya rendah sebanyak 15 siswa dengan persentase sebesar 13,6\%. Siswa dengan dukungan teman sebaya sedang sebanyak 79 siswa dengan persentase $71,8 \%$. Siswa dengan dukungan teman sebaya tinggi sebanyak 16 siswa dengan persentase $14,5 \%$. 
Table 1. Data Hasil hubungan dukungan teman sebaya

\begin{tabular}{ccccc}
\hline $\begin{array}{c}\text { Tingkat } \\
\text { Dukungan } \\
\text { Teman Sebaya }\end{array}$ & Rentang Skor & $\begin{array}{c}\text { Jumlah } \\
\text { Responden }\end{array}$ & Persentase & Klasifikasi \\
\hline Rendah & $\leq 67$ & 15 & $13,6 \%$ & Sangat \\
& $67-79$ & 79 & $71,8 \%$ & Sedikit \\
Sedang & $>79$ & 16 & $14,5 \%$ & Banyak \\
Tinggi & Total & 110 & $100 \%$ & Sedikit \\
& & & & \\
\hline
\end{tabular}

Berdasarkan hasil kategori di atas dapat disimpulkan bahwa dukungan teman sebaya yang dimiliki oleh siswa SMA Negeri 1 Tarakan sebagian besar tergolong dalam kategori sedang.

\subsubsection{Kecerdasan emosional siswa SMA Negeri 1 Tarakan}

Hasil analisis data kecerdasan emosional menggambarkan kecerdasan emosional siswa di SMA Negeri 1 Tarakan secara umum. Kecerdasan emosional dilihat dari 3 kategori yaitu: tinggi, sedang, dan rendah. Siswa dengan kecerdasan emosional rendah sebanyak 14 siswa dengan persentase sebesar 12,7\%. Siswa dengan kecerdasan emosional sedang sebanyak 79 siswa dengan persentase $71,8 \%$. Siswa dengan kecerdasan emosional tinggi sebanyak 17 siswa dengan persentase $15,5 \%$.

Tabel 2. Data Hasil kecerdasan emosional

\begin{tabular}{ccccc}
\hline $\begin{array}{c}\text { Kategori } \\
\text { Kecerdasan } \\
\text { Emosional }\end{array}$ & Rentang Skor & $\begin{array}{c}\text { Jumlah } \\
\text { Responden }\end{array}$ & Persentase & Klasifikasi \\
\hline Rendah & $<40$ & 14 & $12,7 \%$ & $\begin{array}{c}\text { Sangat } \\
\text { Sedikit }\end{array}$ \\
\hline Sedang & $40-50$ & 79 & $71,8 \%$ & Banyak \\
\hline Tinggi & $>50$ & 17 & $15,5 \%$ & Sedikit \\
\hline & Total & 110 & $100 \%$ & \\
\hline
\end{tabular}

Hasil kategori di atas dapat disimpulkan bahwa kecerdasan emosional yang dimiliki oleh siswa SMA Negeri 1 Tarakan sebagian besar tergolong dalam kategori sedang.

\subsubsection{Perilaku hedonis siswa SMA Negeri 1 Tarakan}

Hasil analisis data perilaku hedonis menggambarkan perilaku hedonis siswa di SMA Negeri 1 Tarakan secara umum. Perilaku hedonis dilihat dari 3 kategori yaitu: tinggi, sedang, dan rendah. Siswa dengan perilaku hedonis rendah sebanyak 12 siswa dengan persentase sebesar $10,9 \%$. Siswa dengan perilaku hedonis sedang sebanyak 80 siswa dengan persentase $72,7 \%$. Siswa dengan perilaku hedonis tinggi sebanyak 18 siswa dengan persentase $16,4 \%$. 
Tabel 3. Data Hasil perilaku hedonis

\begin{tabular}{ccccc}
\hline $\begin{array}{c}\text { Tingkat } \\
\text { Perilaku } \\
\text { Hedonis }\end{array}$ & $\begin{array}{c}\text { Rentang } \\
\text { Skor }\end{array}$ & $\begin{array}{c}\text { Jumlah } \\
\text { Responden }\end{array}$ & Persentase & Klasifikasi \\
\hline Rendah & $\leq 28$ & 12 & $10,9 \%$ & Sangat \\
Sedang & $28-42$ & 80 & $72,7 \%$ & Sedikit \\
Tinggi & $>42$ & 18 & $16,4 \%$ & Banyak \\
& Total & 110 & $100 \%$ & Sedikit \\
\hline
\end{tabular}

Hasil kategori di atas dapat disimpulkan bahwa perilaku hedonis yang dimiliki oleh siswa SMA Negeri 1 Tarakan sebagian besar tergolong dalam kategori sedang.

\subsubsection{Hasil Uji Koefisien Determinasi $\left(\mathrm{R}^{2}\right)$}

Uji ini bertujuan untuk menentukan proporsi atau persentase total variasi dalam variabel dependen yang diterangkan oleh variabel independen. Pada penelitian ini menggunakan nilai $\mathrm{R}$ square. Jika $\mathrm{R}^{2}$ yang diperoleh mendekati 1 maka dikatakan semakin kuat model tersebut menerangkan hubungan variabel independen terhadap variabel dependen.

Tabel 4. Hasil Uji Koefisien Determinasi

\begin{tabular}{|c|c|c|c|c|c|c|c|c|c|}
\hline \multirow{2}{*}{ Model } & \multirow[t]{2}{*}{$\mathbf{R}$} & \multirow{2}{*}{ R Square } & \multirow{2}{*}{$\begin{array}{l}\text { Adjusted } \\
\text { R Square }\end{array}$} & \multirow{2}{*}{$\begin{array}{c}\text { Std. Error } \\
\text { of the } \\
\text { Estimate }\end{array}$} & \multicolumn{5}{|c|}{ Change Statistics } \\
\hline & & & & & $\begin{array}{c}\text { R Square } \\
\text { Change }\end{array}$ & F Change & df1 & df2 & $\begin{array}{c}\text { Sig. F } \\
\text { Change }\end{array}$ \\
\hline 1 & $.298 \mathrm{a}$ & .089 & .071 & 6.926 & .089 & 5.196 & 2 & 107 & .007 \\
\hline
\end{tabular}

Berdasarkan tabel 4 tersebut terkait hasil koefisien determinasi $\left(\mathrm{R}^{2}\right)$, didapatkan nilai $\mathrm{R}$ square 0,089 atau sama dengan $8,9 \%$. Artinya, variabel dukungan teman sebaya (X1) dan kecerdasan emosional (X2) secara simultan berhubungan dengan variabel perilaku hedonis (Y) sebesar 8,9\%, sedangkan besar hubungan variabel perilaku hedonis yg ditimbulkan faktor lain ialah sebesar $91,1 \%$.

\subsubsection{Hasil uji F}

Pengujian pada penelitian ini menggunakan tingkat signifikansi 0,05. Apabila probabilitas $<0,05$ maka dapat dikatakan bahwa Ho ditolak maka H1 diterima.

Tabel 5 hasil uji F

\begin{tabular}{cccccccccc}
\hline Model & $\mathbf{R}$ & $\begin{array}{c}\text { R } \\
\text { Square }\end{array}$ & $\begin{array}{c}\text { Adjusted } \\
\text { R Square }\end{array}$ & $\begin{array}{c}\text { Std. Error } \\
\text { of the } \\
\text { Estimate }\end{array}$ & $\begin{array}{c}\text { R Square } \\
\text { Change }\end{array}$ & $\begin{array}{c}\text { Change Statistics } \\
\text { Change }\end{array}$ & df1 & df2 & Sig. F \\
Change
\end{tabular}

a. Predictors: (Constant), ke, ts

Berdasarkan tabel 4.9 hasil uji F didapatkan hasil F hitung sebesar (5.196) lebih dari F tabel $(3,08)$ atau nilai signifikansi $(0,007)$ kurang dari alpha $(0,050)$. Sehingga dapat diinterpretasikan pada dukungan teman sebaya dan kecerdasan emosional secara simultan mempunyai hubungan dengan perilaku hedonis. 


\subsubsection{Hasil uji T}

Pengujian pada penelitian ini menggunakan tingkat signifikansi 0,05. Apabila probabilitas $<0,05$ maka dapat dikatakan bahwa H1 diterima dan Ho ditolak.

Tabel 6 Hasil Uji T

\begin{tabular}{|c|c|c|c|c|c|c|}
\hline & \multirow{2}{*}{ Model } & \multicolumn{2}{|c|}{ Unstandardized Coefficients } & \multirow{2}{*}{$\frac{\text { Standardized Coefficients }}{\text { Beta }}$} & \multirow{2}{*}{ t } & \multirow{2}{*}{ Sig. } \\
\hline & & B & Std. Error & & & \\
\hline \multirow[t]{3}{*}{1} & (Cons & 56.435 & 8.366 & & 6.746 & .000 \\
\hline & Ts & -.036 & 108 & -.032 & -.331 & .741 \\
\hline & $\mathrm{Ke}$ & -.400 & .136 & -.286 & -2.944 & .004 \\
\hline
\end{tabular}

a. Dependent Variable: ph

Berdasarkan hasil uji T pada tabel 6 menunjukan bahwa hubungan dukungan teman sebaya (X1) dengan perilaku hedonis (Y) memiliki nilai signifikansi yaitu $0,000<0,05$, artinya variabel hubungan dukungan teman sebaya dengan perilaku hedonis secara signifikan berhubungan. Hasil uji t pada variabel kecerdasan emosional (X2) dengan perilaku hedonis (Y) memiliki nilai signifikansi $0,004<0,05$, artinya variabel kecerdasan emosional dengan perilaku hedonis secara signifikan berhubungan.

Sumbangan efektif dalam penelitian ini untuk mengetahui besarnya sumbangan efektif tiap variabel bebas. Berdasarkan hasil penelitian diketahui bahwa nilai sumbangan efektif untuk dukungan teman sebaya dengan perilaku hedonis sebesar $0,4 \%$ sedangkan nilai sumbangan efektif untuk kecerdasan emosional dengan perilaku hedonis sebesar 8,5\% dan sumbangan efektif dukungan teman sebaya dan kecerdasan emosional secara bersama-sama dengan terhadap perilaku hedonis sebesar 8,9\%.

\subsection{Pembahasan}

Hasil analisis deskriptif menunjukkan bahwa persentase 71,8 dalam kategori sesertag, Hal ini menunjukkan bahwa dukungan teman di SMA Negeri 1 tarakan mampu memberikan dukungan kepada teman sebaya dengan baik. Seperti yang diungkapkan oleh (Dusek, 1996) pada masa remaja lebih banyak menghabiskan waktunya buat teman dekat berkembang sehingga teman dekat merajai jumlah aspek perkembangan lebih berlimpah daripada saat kanak-kanak.

Sehubungan dengan dampak penelitian yg sudah dilakukan, diperoleh hasil berarti terdapat hubungan antara dukungan teman sebaya dengan perilaku hedonis siswa SMA Negeri 1 Tarakan. Hal ini dikatakan mulai hasil uji regresi yang dilakukan dengan melihat nilai signifikansi sebesar $\mathrm{p}=0,00<0,05$. Artinya hipotesis nol ditolak dan hipotesis 1 diterima. Terdapat hubungan negatif yg signifikan antara dukungan teman sebaya dengan perilaku hedonis dengan koefisien korelasi sebesar -0,121. Hasil analisis berarti penelitian ini menunjukan maka dukungan teman sebaya memiliki hubungan yang negatif atas perilaku hedonis. Semakin tinggi dukungan teman sebaya hingga terus menjadi rendah pula sikap hedonis siswa kebalikannya terus menjadi rendah dorongan sahabat sebaya hingga semakin besar pula sikap hedonis siswa. Perihal ini sejalan dengan riset yang dicoba oleh Rianton menimpa hubungan antara konformitas kelompok teman sebaya atas style hidup hedonis akan mahasiswa kab. Dharmasraya di Yogyakarta. Dari riset ini menyatakan kalau dorongan teman 
sebaya ialah salah satu aspek yang sangat mempengaruhi dalam sikap hedonis dengan sumbangan efisien sebesar 23\%. Hasil riset tersebut didukung oleh komentar Kelly serta Hansen (dalam Desmita, 2010) salah satu guna positif sahabat sebaya ialah dapat menaikkan keahlian-keahlian sosial, menyebarkan keahlian penalaran, \& belajar buat mengekspresikan perasaan memakai metode yg lebih matang.

Hasil analisis deskriptif menunjukkan bahwa persentase 71,8 dalam kategori sedang. Seperti hal yang diungkapkan oleh Anastasi \& Urbina (2007) kecerdasan menurutnya makin atas keberhasilan yg boleh mendapatkan seseorang dalam mengembangkan serta menggunakan kemampuan yg merajai pembiasaan emosional, hubungan antar pribadi, serta konsep diri yg memiliki individu.

Sehubungan dengan hasil penelitian yang sudah dilakukan, diperoleh hasil berarti terdapat hubungan antara kecerdasan emosional dengan perilaku hedonis siswa SMA Negeri 1 Tarakan. Hal ini dibuktikan dari hasil uji regresi yang dilakukan dengan melihat nilai signifikansi sebesar $p=0,00<0,05$. Artinya hipotesis nol ditolak dan hipotesis penelitian diterima, yang terdapat hubungan negatif yang signifikan antara kecerdasan emosional dengan perilaku hedonis dengan koefisien korelasi sebesar -0,296.

Hasil analisis dalam penelitian ini menunjukan bahwa kecerdasan emosional memiliki hubungan yang negatif dengan perilaku hedonis. Semakin tinggi kecerdasan emosional siswa maka semakin rendah perilaku hedonis siswa sebaliknya semakin rendah kecerdasan emosional maka semakin tinggi perilaku hedonis siswa. Ameriks, Wranik, \& Salovey (2009), dalam penelitiannya bahwa perilaku hedonis seseorang dipengaruhi oleh kecerdasan emosional orang sebagai bagian dari sikap seseorang pada mengelola keuangan pribadinya. Lalu dikenal pada kepribadian dan kecerdasan emosional berakibat terhadap keputusan individu ketika mengelola keuangannya. Terdapat pengaruh psikologis seorang pada pengambilan keputusan keuangan yang dimilikinya. perihal ini sama dengan riset yang dicoba oleh Pulungan, Koto, Syahfitri (2018) dalam Kecerdasan emosional teruji sanggup pengaruhi sikap keuangan mahasiswa Prodi Manajemen Fakultas Ekonomi dan Bisnis UMSU secara positif serta signifikan. maksudnya kecerdasan emosional mahasiswa sanggup secara kokoh serta membagikan pengaruh secara nyata buat mengganti sikap hedonis mahasiswa khususnya nampak pada pengambilan keputusan kala memakai uang yg dipunyai buat kebutuhannya tiap hari. Berdasarkan analisis regresi linier berganda dan hasil uji t diperoleh nilai sig $0,000<0.05$. Kecerdasan emosional yang dipunyai mahasiswa mempunyai pengaruh positif serta signifikan terhadap sikap keuangan mahasiswa dengan besar pengaruh ialah sebesar 0,538 atau 53,80 \%. Hasil survei membagikan informasi bahwa mahasiswa Prodi Manajemen Fakultas Ekonomi dan Bisnis UMSU memiliki kecerdasan emosional masuk dalam jenis baik.

Berdasarkan banyaknya faktor pembentuk perilaku hedonis menunjukan bahwa faktorfaktor yang lain bisa menjadi faktor yang lebih kuat berarti melatih perilaku hedonis siswa di SMA Negeri 1 Tarakan. Akan tetapi mulai pembeberan di atas dapat disimpulkan maka hipotesis penelitian diterima yaitu dukungan teman sebaya serta kecerdasan emosional secara bersama-sama berhubungan atas perilaku hedonis siswa SMA Negeri 1 Tarakan. Hal ini berguna semakin banyak tingkat dukungan teman sebaya serta kecerdasan emosional siswa, bahwa tingkat perilaku hedonis yang dimiliki siswa akan semakin tinggi, dibuktikan dengan asertaya hubungan yang signifikan antara dukungan teman sebaya, kecerdasan emosional atas 
perilaku hedonis siswa SMA Negeri 1 Tarakan dengan nilai korelasi antara variabel dukungan teman sebaya serta kecerdasan emosional dengan perilaku hedonis sebesar 8,9\%. Dengan masing-masing sumbangan efektif dari variabel dukungan teman sebaya dengan perilaku hedonis sebesar $0,4 \%$ serta sumbangan efektif variabel kecerdasan emosional dengan perilaku hedonis sebesar $8,5 \%$.

Bimbingan dan konseling mempunyai posisi yg sangat penting buat menangani siswa di Sekolah. Oleh karena itu, sudah merupakan tugas bimbingan dan konseling untuk membantu siswa mencapai tugas-tugas perkembangannya sesuai dengan peraturan Depdiknas (2007) mengenai rambu-rambu penyelenggaraan bimbingan dan konseling. Tujuan penelitian hubungan antara dukungan teman sebaya dan kecerdasan emosional dengan perilaku hedonis ini bisa membantu guru BK untuk mengetahui faktor-faktor yang memberikan hubungan paling besar terhadap perilaku hedonis. Dengan hasil penelitian ini bisa dikembangkan langkah-langkah melalui program bimbingan di sekolah ataupun dapat dijadikan acuan awal dalam pembuatan pedoman siswa di SMA Negeri 1 Tarakan. Guru BK dalam memberikan layanan dapat berkolaborasi dengan pihak-pihak terkait untuk mengurangi perilaku hedonis. Kolaborasi yang dilakukan oleh guru BK adalah bersama orang tua dan wali kelas dalam mengurangi perilaku hedonis. Program yang dibuat oleh guru bimbingan dan konseling dapat membantu siswa untuk menurunkan perilaku hedonisnya dengan memberikan konseling kelompok dengan pendekatan behavior untuk mengurangi perilaku hedonis.

\section{Simpulan}

Berdasarkan hasil penelitian dan pembahasannya dapat diambil kesimpulan bahwa terdapat hubungan negatif antara dukungan teman sebaya dengan perilaku hedonis, terdapat hubungan negatif antara kecerdasan emosional dengan perilaku hedonis dan terdapat hubungan yang signifikan antara dukungan teman sebaya dan kecerdasan emosional secara bersama-sama dengan perilaku hedonis di SMA Negeri 1 Tarakan. Sumbangan efektif dukungan teman sebaya terhadap perilaku hedonis sebesar 0,4\%, sumbangan efektif kecerdasan emosional terhadap perilaku hedonis sebesar 8,5\%, dan sumbangan efektif dukungan teman sebaya dan kecerdasan emosional secara bersama-sama terhadap perilaku hedonis sebesar $8,9 \%$.

Adapun saran yang disampaikan untuk guru bimbingan dan konseling yaitu Hasil penelitian ini dapat dijadikan informasi dan acuan oleh guru BK mengembangkan program dalam mencegah munculnya perilaku hedonis melalui peningkatan dukungan teman sebaya dan kecerdasan emosional. Saran untuk peneliti selanjutnya ialah Hasil penelitian ini dapat menjadi acuan kepada peneliti selanjutnya bahwa banyak aspek selain dukungan teman sebaya dan kecerdasan emosional yang dapat mempengaruhi perilaku hedonis seperti faktorfaktor yang mempengaruhi perilaku hedonis serta dapat menjangkau penelitian yang yang luas

\section{Daftar Rujukan}

Ameriks, J., Wranik, T., \& Salovey, P. (2009). Emotional Intelligence and Investor Behavior. The Reseach Foundation of CFA Institute.

Anastasi, A. \& Urbina, S. (2007). Psychological Testing. New Jersey: Prentice Hall Inc

Anggraini, R. T., \& Santhoso, F. H. (2017). Hubungan antara Gaya Hidup Hedonis dengan Perilaku Konsumtif pada Remaja. Gadjah Mada Journal of Psychology (GamaJoP), 3(3), 131-140. 
Ardana, I. C., R Aritonang, L., \& Sugiarto Dermawan, E. (2013). Kecerdasan Intelektual, Kecerdasan Emosional, Kecerdasan Spiritual, Dan Kesehatan Fisik Untuk Memprediksi Prestasi Belajar Mahasiswa Akuntansi (Studi Empiris Pada Mahasiswa Tingkat Akhir (Skripsi) S1 Akuntansi FE Untar).

Arikunto, S. (2013). Prosedur Penelitian: Suatu Pendekatan Praktik. Jakarta: Rineka Cipta.

Azwar, S. (2009). Metode Penelitian. Yogyakarta: Pustaka Pelajar

Bagon, S. (2013). Sosiologi Ekonomi: Kapitalisme dan Konsumsi di Era Masyarakat Post-Modernisme. Jakarta: Kencana Prenada Media.

Bertens, K. (1994). Etika. Jakarta. PT Gramedia Pustaka Utama

Daud, F. (2012). Pengaruh kecerdasan emosional (EQ) dan motivasi belajar terhadap hasil belajar Biologi siswa SMA 3 Negeri Kota Palopo. Jurnal Pendidikan dan Pembelajaran (JPP), 19(2), 243-255.

Delyana R. P., Murviana, K, \& Lena, S. (2018). Pengaruh Gaya Hidup hedonis dan Kecerdasan Emosional Terhadap Perilaku Keuangan Mahasiswa. Jurnal Seminar Nasional Royal.

Amstrong, G. \& Kotler, P., (1997). Prinsip-prinsip Pemasaran. Cetakan Pertama, Erlangga Jakarta.

Fauziah, E. M. (2016). Pengaruh Teman Sebaya terhadap Perilaku Seksual Remaja. Jurnal Ilmiah Bidan, 1(2)

Fahmi, J. Z. (2019). Keefektifan Teknik Self-Management untuk Mereduksi gaya hidup hedonis siswa SMA. Tesis tidak diterbitkan. FIP UM

Firdaus, D. (2012). Pengaruh Kecerdasan Emosional (EQ) dan Motivasi Belajar terhadap Hasil Belajar Biologi Siswa SMA 3 Negeri Kota Palopo. Jurnal Pendidikan dan Pembelajaran, 19(2)

Ghozali, I. (2011). Aplikasi Analisis Multivariate dengan Program SPSS. Semarang: Badan Penerbit Universitas Diponegoro.

Goleman, D. (2002). Emotional Intelligence. Why it can metter than IQ. London: Bloomsbury

Goleman, D. (2000). Emotional Intelligence. Jakarta: PT Gramedia Pustaka Utama.

Goleman, D. (2009). Kecerdasan Emosional: Mengapa EI lebih penting daripada IQ. Jakarta: PT. Gramedia Pustaka Utama.

Gunarsa \& Gunarsa. (1995). Psikologi Praktis: anak, remaja, dan keluarga. Jakarta: Gunung Mulia.

Gusniwati, M. (2015). Pengaruh kecerdasan emosional dan minat belajar terhadap penguasaan konsep matematika siswa SMAN di Kecamatan Kebon jeruk. Formatif: Jurnal Ilmiah Pendidikan MIPA, 5(1).

Haryadhi, R. H. D. (2018). Hubungan Dukungan Sosial Teman Sebaya dan Self Esteem dengan Kepercayaan Diti Siswa Kelas VII Madrasah Tsanawiyah Negeri 1 Pamekasan. Skripsi tidak diterbitkan. FIP.UM

Hasan, S. A., Handayani, M. M., \& Psych, M. (2014). Hubungan antara dukungan sosial teman sebaya dengan penyesuaian diri siswa tunarungu di sekolah inklusi.Jurnal Psikologi pendidikan dan perkembangan, 3(2), 128-135.

Hidayah, M. (2018). Hubungan Dukungan Teman Sebaya dan Stres Akademik pada Siswa SMA Boarding School.

Hurlock, E. B. (1993). Psikologi Perkembangan: Suatu Pendekatan Sepanjang Rentang Kehidupan. Jakarta: Erlangga

Kartini \& Kartono. (1997). Patologi Sosial. Jakarta: CV. Rajawali

Kasali, R. (1998). Membidik Pasar Indonesia: Segmentasi, Targetting, Positioning. Jakarta: Gramedia Pustaka Utama.

Martha, D. (2008). Correlation Among Self EsteemWith a Tendency Hedonist Lifestyle of Student Dipo $\urcorner$ negoro University. Journal of Applied Psychology. Semarang: FAPSI UNDIP.

Melka, F. D., Ahmad, R., Firman, Y. S., Sukmawati, I., \& Handayani, P. G. (2017). Hubungan Kecerdasan Emosional dengan Penerimaan Teman Sebaya serta Implikasinya dalam Bimbingan dan Konseling. Jurnal Neo Konselor.

Nadia F. S. \& Endang S. I. (2018) Hubungan Konformitas Teman Sebaya dengan Gaya Hidup Hedonis pada Siswa di SMA PL Don Bosco Semarang. Jurnal empati, 7(2)

Naomi, P., \& Mayasari, I. (2008). Faktor-faktor yang mempengaruhi siswa SMA dalam perilaku pembelian kompulsif: Perspektif Psikologi. Portal Jurnal UPI, 8(8) 
Jurnal Pembelajaran, Bimbingan, dan Pengelolaan Pendidikan, 1(5), 2021, 346-355

Papalia, D. E., Olds, S. W., \& Feldman, R. D. (2009). Human development: Perkembangan manusia. Jakarta: Salemba Humanika.

Praja, D.D., \& Damayantie, A. (2010). Potret gaya hidup hedonisme di kalangan mahasiswa (Studi pada mahasiswa Sosiologi FISIP Universitas Lampung). Jurnal Sociologie, 1(3), 184-190

Prasetyo, D. (2015). Tingkat Kecerdasan Emosional Peserta Didik yang Mengikuti Ekstrakulikuler Olahraga Beregu di SMA N 1 Karanganyar Kebumen. Skripsi. FIK.UNY

Saputro, D. W. (2014). Hubungan antara Relasi Pertemanan dengan Gaya Hidup Hedonis pada Eksekutif Muda (skripsi). Surakarta: Universitas Muhammadiyah Surakarta. 